\title{
Kentucky
}

Fatality

\section{Assessment and Control}

\section{Evaluation Project}

TO: Michael Auslander, DVM, MSPH, Kentucky Department for Public Health, Division of Epidemiology, Surveillance and Investigations Branch

FROM: $\quad$ Medearis Robertson, KY FACE Field Investigator and Tim Struttmann, MSPH, KIPRC Acting Director

SUBJECT: Youth Riding as Passenger on Tractor Killed by Overturn

\section{SUMMARY}

A 16-year-old female was killed after the tractor on which she was riding as a passenger overturned. She was a high school student; farmed on evenings and weekends. The tractor was driven by a 20 -year-old friend while baling hay on a farm at dusk. The driver and the victim had been baling hay all day, and both were experienced farmers. The victim was seated on the fender to the left of the driver. The tractor was a 1969 tricycle-tired John Deere, which was well maintained but was not equipped with a Roll Over Protective Structure (ROPS) or a seatbelt. The tires were appropriately fluid filled. The driver was reversing the tractor down a slight slope in an open field in order to stab a bale of hay with an attached hayfork. The right rear wheel ran over the hay bale causing the tractor to overturn side-ways on top of the victim and the driver. The driver was pushed clear by one of the tractor's rotating wheels. The victim was pinned underneath the tractor's driver seat and died of compression asphyxiation.

In order to prevent similar incidents, the Kentucky FACE investigators recommend that:

- Individuals should not ride as passengers on an operating tractor, and drivers should not allow extra riders/passengers.

- Tractor should be equipped with rollover protective structures and seatbelts.

- Farmers should exercise extra caution using tractors when their ability to see is compromised: e.g. when it is getting dark which may limit visibility, and when operating in reverse.

- Tractors should be equipped with front-end counterweights.

Young farm equipment operators should educate themselves with safety courses and materials, and adhere to recommended operating procedures.

\section{INTRODUCTION}


On October $14^{\text {th }}, 2001$ FACE investigators were notified by the county coroner of the death of a 16-year-old female involved in a tractor overturn. The incident occurred on October $13^{\text {th }}$. The coroner was interviewed over the phone on October $18^{\text {th }}$ and two KY FACE investigators accompanied by a KY State Police Trooper conducted an on-site investigation on October $21^{\text {st }}$. Photos and measurements were taken of the scene and the tractor, and investigators interviewed the father of the tractor driver, who had witnessed the immediate aftermath of the incident. A copy of the police trooper's unofficial report was made available to the investigators, and newspaper articles on the incident were obtained.

The victim in this case was accompanying her companion, the driver of the tractor, whom she had known for several months. The companion had worked as a contract farmer on a 128-acre deer farm. He had been farming all his life, and had been farming the deer farm independently for 3 years. The victim came from a farming family and was familiar with the equipment. It is unknown whether the driver or victim had received any formal farm safety training.

\section{INVESTIGATION}

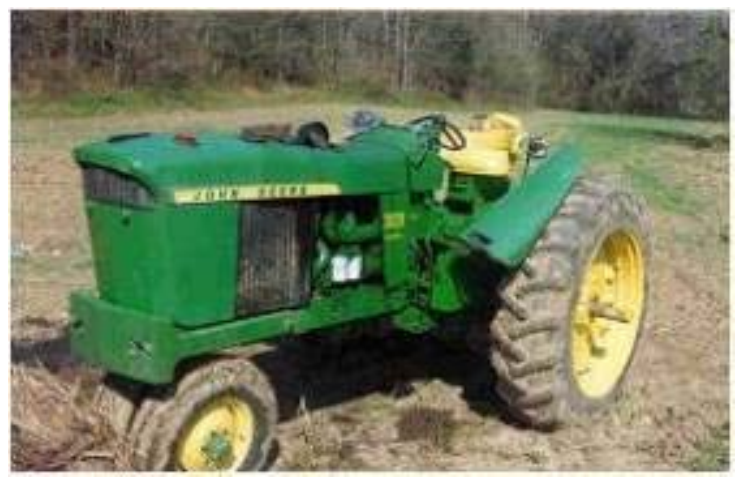

On the day of the incident the driver of the tractor and the victim had been baling hay since morning. At approximately 19:30 the victim was accompanying the driver and was seated on the fender over the left wheel of the tractor (see Figure 1). The tractor was a 65 horsepower diesel-powered John Deere 1969 tricycle, Model 3020, which the driver had bought used 2 years prior. The rear tires were spread 67” apart (center to center). This 6200-pound tractor (Official Guide - Tractors and Farm Equipment ${ }^{1}$ ) was designed as a general-purpose farm tractor. The tractor and its tires were in good condition prior to the incident and the brakes were functioning. The tractor was not equipped with a ROPS or seatbelt. The rear tires were fluid filled to approximately the same level, one-third to one-half full. The tractor had no front-end counter weights for greater stability.

Figure 1. Tractor that overturned showing fender on which victim had been sitting.

The weather was cloudy and about 70 degrees. Rainfall a couple of days prior to the day of the incident had left the ground somewhat muddy. The driver was attempting to load a bale of hay onto a 3.5 foot spike that was 2 inches in diameter. It was dusk and the tractor had its headlights on. The tractor had been moving backwards towards the bale of hay in a westerly direction down a slope that declined approximately 1 inch per foot, increasing to a slope of approximately 


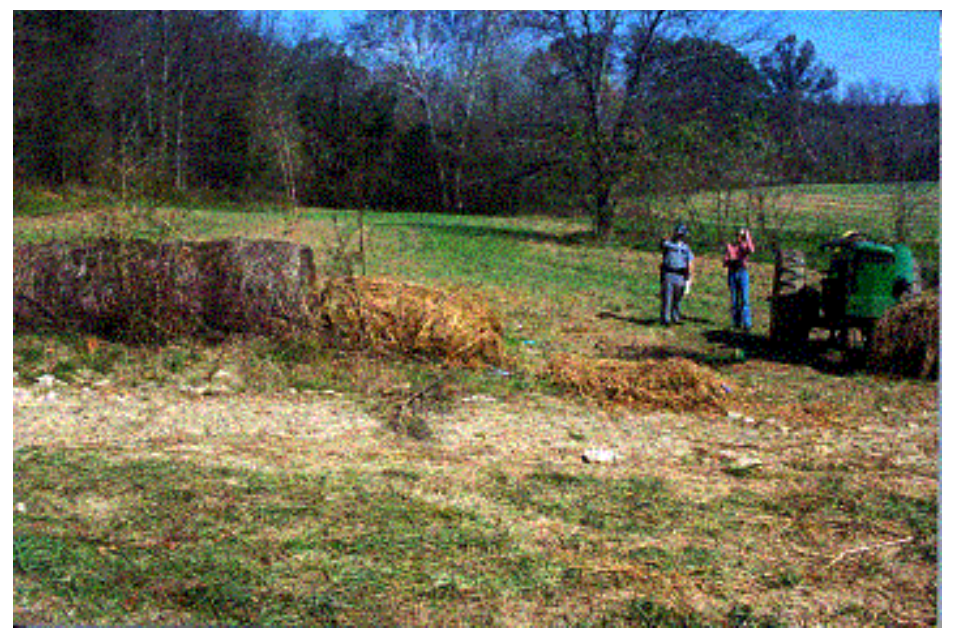

Figure 2. Site of Tractor Incident.

2 inches per foot at the spot where the tractor overturned (see Figure 2). As it reversed, the right rear wheel of the tractor proceeded over the hay bale causing the tractor to overturn sideways to the left (see Figure 3). According to the driver's father, the driver reported that both the victim and the driver each attempted to push the other free of the falling tractor. The victim was trapped underneath the driver's seat. The driver was thrown clear by a rotating tire, but sustained damage to his lungs and ribs. Nevertheless he attempted to free the victim. When he was unable to free her, he started up the nearby road on a steep hill that led to his home, a quarter mile away.

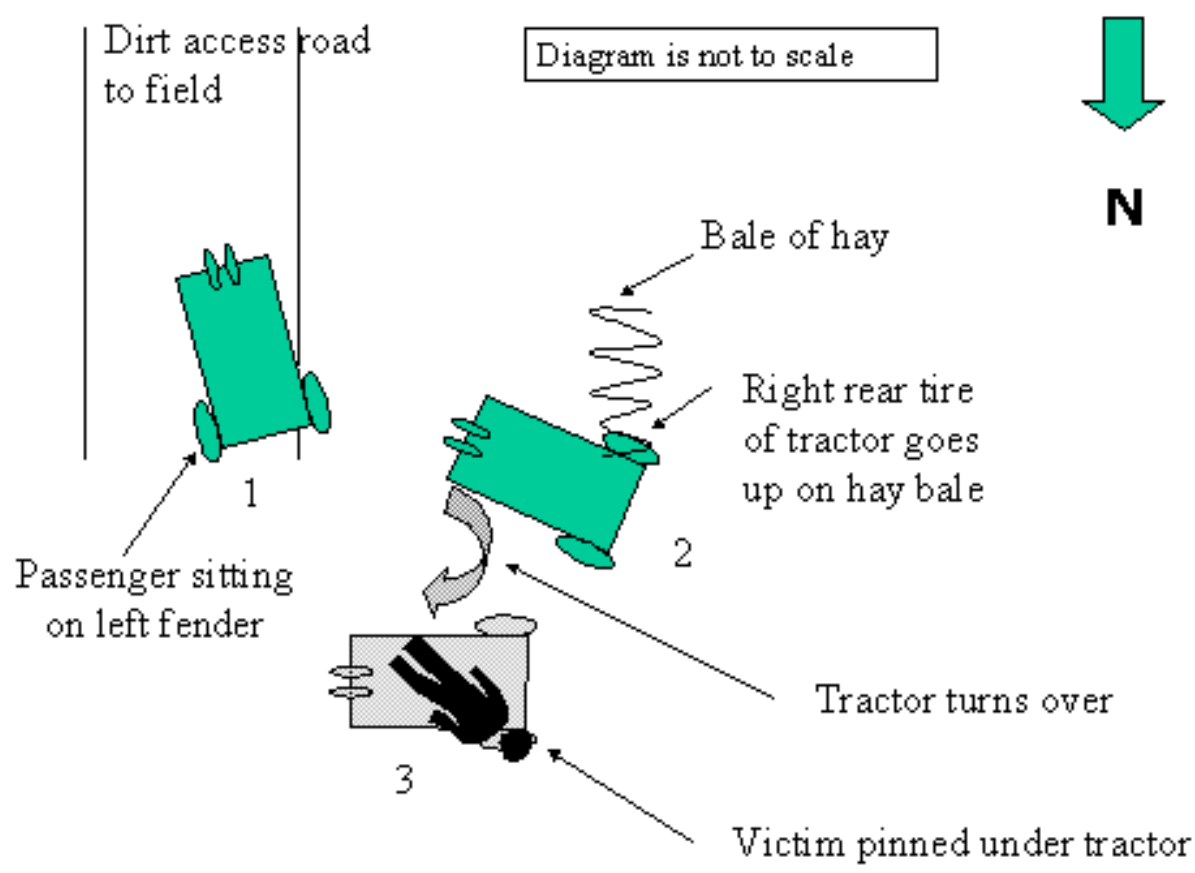

Figure 3. Schematic diagram showing sequence of tractor overturn and final position of victim.

The father of the driver was working in an adjacent field without visual access to the field in which the incident occurred. When he no longer heard his son's tractor running he went over to investigate. The father called EMS, who arrived at the scene 16 minutes after being called. A Kentucky State Police Trooper arrived at the scene minutes later. EMS used airbags to lift the tractor and free the victim. The victim arrived at the hospital almost two hours after the incident occurred and was pronounced dead from compression 
asphyxiation about two hours after arrival at the hospital.

The tractor suffered minor damage such as: left side fender was bent, steering wheel broken, seat bent, exhaust stack bent over, right hand mounting fender bracket broken, air intake valve sheared off.

By the time the FACE investigators arrived at the scene, the tractor had been pulled upright.

\section{RECOMMENDATIONS and DISCUSSION}

Recommendation \#1: Individuals should not ride as passengers on an operating tractor, and drivers should not allow extra riders/passengers.

Discussion \#1: Tractors are designed for one operator with one set of controls and do not have passenger seats. A space is available for a person to sit on the fender; however, this is not the designers' intent. An estimated 1,100 youth less than 20 years old were injured in tractor related incidents in the United States during 1998 (CDC DHHS June 2001) ${ }^{2}$, some of these severe enough to be fatal.

Recommendation \#2: Tractor should be equipped with rollover protective structures and seatbelts.

Discussion \#2: Rollover protective structures prevent deaths ${ }^{3}$. The tractor involved in this incident, manufactured in 1969, was not equipped with ROPS or a seatbelt, which protect the operator in the event of a rollover, and in this case might have prevented a 180 degree overturn by the tractor. ROPS first became available as optional equipment on farm tractors in 1971. These safety features were not required on tractors, however, until 1976, when OSHA Standard 29 CFR $1928.51^{4}$ went into effect. Although this standard does not apply to tractors manufactured prior to 1976, and thus would not apply to the 1969 model tractor in this case, it is possible to retrofit older tractors with ROPS and seatbelts, and it is strongly recommended that this be done whenever possible. Tractor owners should contact dealers, manufacturers, or county extension agents for information on sources of retrofit ROPS and operator restraint systems. A retrofit ROPS is available for this tractor (A Guide To Agricultural Tractor Rollover Protective Structures ${ }^{5}$ ).

Recommendation \#3: Farmers should exercise extra caution using tractors when visibility is compromised.

Discussion \#3: This incident occurred at dusk when visibility was limited. Further, the shadow of a hill reduced visibility. Even though the tractor lights were on, the operator was looking backwards to stab the bale. Operators should exercise extra caution when operating their tractors in conditions of fading light.

Recommendation \#4: Tractors should be equipped with front-end counterweights.

Discussion \#4: Additional weight on the front of this tractor would have increased its stability and steering capabilities. While proceeding in reverse down a slight grade, the steering is affected by a reduction of the downward forces on the front wheels. To counteract, additional weights should be added to the front of the tractor. In addition, rear wheel weights are available and would add additional stability.

Recommendation \#5: Young farm equipment operators should educate themselves with safety courses and materials, and adhere to recommended operating procedures.

Discussion \#5: Young people working on farms should be offered safety courses and materials to identify 
hazards, evaluate risk and develop safe operating practices. Offering such information to young people through $4 \mathrm{H}$ clubs, county extension agents and vocational education provides safety education and an avenue for prevention and intervention.

Recommendation \#6: When purchasing used equipment, if it is not equipped with ROPS and/or seatbelts, such devices should be installed.

Discussion \#6: In a conversation with John Deere, the cost to retrofit a John Deere 19693020 diesel tricycle tractor with a ROPS device is approximately $\$ 700$ - $\$ 750$ (installed by owner), and takes one hour or less to install. Market price for this tractor is around $\$ 5,000-\$ 6,000$.

\section{REFERENCES}

1. Official Guide - Tractors and Farm Equipment, North American Equipment Dealers Association Fall 1994 Edition.

2. US Department of Health and Human Services, Centers for Disease Control and Prevention National Institute for Occupational Safety and Health. Injuries Among Youth on Farms in the United States. June 2001 DHHS (NIOSH) Publication No. 2001-154; 25

3. US Department of Health and Human Services, PHS, Centers for Disease Control and Prevention National Institute for Occupational Safety and Health. Update. NIOSH Reports on the Preventability of Tractor Rollovers. January 29, 1993. MMWR 42(03);57-59.

4. Standard Number 1928.51, Subpart C, US Department of Labor, Occupational Safety and Health Administration, OSHA CD-ROM (OSHA A94-2), February 1994.

5. A Guide to Agricultural Tractor Rollover Protective Structures. National Farm Medicine Center Marshfield, WI, 1997; 9 